\title{
THE COMMON COMMERCIAL POLICY AFTER OPINION 2/15: NO SIMPLE WAY TO MAKE LIFE EASIER FOR FREE TRADE AGREEMENTS IN THE EU
}

\author{
Ondřej Svoboda*
}

\begin{abstract}
On 16 May 2017, the Court of Justice of the EU (CJEU) delivered a long-awaited opinion on the legal nature of the free trade agreement between the EU and Singapore (Opinion 2/15). This decision was highly anticipated as it was expected to clarify uncertainties of several aspects of the EU Common Commercial Policy (CCP) which has broadened in scope after the Lisbon Treaty. The CJEU's conclusion on the division of competences and its possible impacts on the CCP immediately sparked a debate within the Union's institutions about its future direction. In particular, the architecture of EU free trade agreements, the dominant tool of the CCP at the beginning of the $21^{\text {st }}$ century, is now under scrutiny. Trade deals without investment provisions could potentially simplify many steps which now burden the treaty-making process. This paper discusses Opinion 2/15 and its significance for the future development of the CCP. It explores and analyses the implications for shaping the post-Lisbon CCP with regard to two specific areas: investment protection and sustainable development. The paper concludes that a new architecture for EU trade agreements could be further improved as there is a potential to preserve the CCP as both an operational and ambitious trade policy. In this respect, comprehensive FTAs encompassing trade, investment and sustainability deserve a second thought in the EU.
\end{abstract}

Keywords: Common Commercial Policy, free trade agreement, competence, investment protection, sustainable development.

\section{Introduction}

On 16 May 2017, the Court of Justice of the EU (CJEU) delivered a long-awaited Opinion on the legal nature of the free trade agreement between the EU and Singapore (EUSFTA). The Opinion was expected to

\footnotetext{
" PhD Candidate in public international law at the Faculty of Law of the Charles University in Prague and a legal officer at the Unit of International Law of the Ministry of Industry and Trade of the Czech Republic, orcid.org/0000-0002-3856-312X. This article was supported by the Charles University, project Progres 804 'Právo v měnícím se světě. The opinions expressed in this article do not represent an official position of the Ministry of Industry and Trade of the Czech Republic and are just and only the author's. I would like to thank Jan Kunstýr̆, Baxter Roberts, two anonymous reviewers and the organisers and participants of the Young Researchers Symposium on 'The Future of Europe' on 8-9 May 2018 at the University of Helsinki. DOI: 10.3935/cyelp.15.2019.350.
} 
bring clarity to the scope of the EU's post-Lisbon Common Commercial Policy (CCP), which has been of paramount importance for the EU's future direction in current turbulent times.

According to the Opinion, the EU's exclusive or shared competence covers all aspects of trade policy in its widest scope designed in recent EU free trade agreements (FTAs), the most prominent and important instrument for regulating trade and investment flows. However, shared competence regarding the two parts of the agreement's investment chapter (indirect investment and the investor-state dispute settlement mechanism) changes the character of the agreement from being solely within the exclusive competence of the EU. Mixity, although it may have different forms, ${ }^{1}$ in practice mostly leads to a situation where both the Member States and the Union are parties to an agreement. Hence, one could easily conclude that without several investment provisions, the EUSFTA, as well as other EU FTAs, would merely be external agreements within the exclusive competence of the Union, with all the legal consequences which relate to the exclusive nature of agreements concluded by the EU. Most importantly, such trade deals would not need to be ratified by each Member State. In non-legal terms, exclusivity can be even understood as a prerequisite for the EU to be active internationally, enhancing the EU's international agency. At the same time, it could also mean a shift of the democratic control from the Member States to the Union. ${ }^{2}$

The Court's conclusion and its impacts on the CCP under current circumstances immediately sparked a debate within the EU's institutions about the next steps for the CCP. The architecture of FTAs has now come under scrutiny, which is accentuated as current bilateral trade negotiations may face strong domestic opposition. The European Commission's request for an Opinion on the scope of the CCP was submitted to the CJEU in the middle of heated public debate on the final text of the Comprehensive and Economic and Trade Agreement (CETA) negotiated between the EU and Canada and the now frozen Transatlantic Trade and Investment Partnership (TTIP) negotiations between the EU and the US. Considering the backlash of civil society organisations against mega-regional trade and investment negotiations, particularly investment protection and investor-state dispute settlement (ISDS), it is easy to reach a conclusion that FTAs without investment provisions can simplify many aspects which currently burden the process and even put the EU's ability to conclude such agreements at risk.

\footnotetext{
1 See Section 3.3.

2 See eg Ramses A Wessel and Tamara Takács, 'Constitutional Aspects of the EU's Global Actorness: Increased Exclusivity in Trade and Investment and the Role of the European Parliament' (2017) 28(2) Business Law Review 103.
} 
However, several other issues arise. For the sake of the exclusive nature of future FTAs, some elements of Member States' competence such as anti-corruption ${ }^{3}$ are being left out of treaty negotiations. This could be detrimental to EU efforts to react to new trends in international trade. In addition, the exclusion of national parliaments from the ratification process of FTAs, as a consequence of their exclusive nature, could raise serious domestic opposition and concerns over the legitimacy of those FTAs. Against this background, the paper will discuss Opinion 2/15 and its significance for the future development of the CCP. It will argue that the EU institutions have chosen the simplest way forward by decoupling investment from the rest of the FTAs, based on the Court's determination of the boundaries of exclusive EU competence. However, this option does not necessarily have to satisfy EU ambitions in trade and investment negotiations, or the expectations of the European public for a more sustainable, inclusive and fairer CCP. ${ }^{4}$ This paper will argue that the old architecture of FTAs, enhanced by strong sustainable development standards interlinked with investment protection, can provide the most suitable solution for the future. Such an approach to EU trade and investment negotiations has the potential to achieve a high level of EU ambitions as well as public acceptance, regardless of continuing mixity.

The article is structured as follows. First, it sets the scene, providing a description of circumstances preceding the signature of the CETA which highlights deficiencies of 'mixed' FTAs. Discussion then follows on the precise context of Opinion 2/15 with respect to investment protection and sustainable development elements of FTAs, as well as the impact on the division of competences between Member States and the EU. Thereafter, the implications in shaping the post-Lisbon CCP, particularly in terms of the new architecture of FTAs, are explored. In this part, we consider the benefits of covering investment and sustainable development issues under one comprehensive agreement, in contrast to the recently adopted practice of separating investment protection in stand-alone agreements. The paper concludes with recommendations for the CCP in

\footnotetext{
3 As stated in the Commission's strategy 'Trade for All' in October 2015 and further discussed in a workshop 'Anti-corruption Provisions in EU Free Trade and Investment Agreements: Delivering on Clean Trade' organised for the European Parliament's Committee on International Trade (INTA) in January 2018. The emerging trend of anti-corruption regulation is also visible in recent texts of the CPTPP and USMCA.

4 European Trade Union Confederation, 'ETUC Resolution for an EU progressive trade and investment policy' (16 June 2017) <www.etuc.org/en/document/etuc-resolution-eu-progressive-trade-and-investment-policy> accessed 15 September 2019; 'Fair, Sustainable and Social: UNI Europa's View on EU Trade Policies' (23 November 2017) <www.uni-europa. org/2017/11/23/fair-sustainable-social-uni-europas-view-eu-trade-policies/> accessed 15 September 2019; The Greens, 'Green Trade for All' (12 June 2018); Commission, 'Meeting report - Civil Society Dialogue on TSD - 29 April 2019' (21 May 2019).
} 
order for it to be an operational trade policy, and one of the stepping stones to the future prosperity of the EU.

\section{On the road to the Court: CETA signature}

The Lisbon Treaty significantly widened the scope of the $\mathrm{CCP}^{5}$ and presented significant progress in the consolidation of the CCP which took place during the years since the Amsterdam Treaty 1999. The inclusion of foreign direct investment (FDI) meant a huge step forward as both trade and investment were for the first time covered by the CCP. Based on the EU's trade strategy 'Global Europe' adopted in $2006,{ }^{6}$ the EU initiated a wave of bilateral trade negotiations. ${ }^{7}$

The CETA is the first comprehensive trade and investment agreement negotiated under the post-Lisbon EU trade policy. The negotiations started in 2009 and the final text was published in February 2016 after a last-minute revision of the investment chapter. ${ }^{8}$ Afterwards, the Commission submitted proposals regarding the signature, provisional application and conclusion of the CETA which treated the CETA as an agreement within the Union's exclusive competence to the Council. As an EU-exclusive agreement, it would not have needed to be signed and ratified by both the EU and the Member States. The ratification procedure in such cases requires only a qualified majority vote (QMV) in the Council and a simple majority in the European Parliament in order to give 'assent'. Under this procedure set out in Article 218 TFEU, the Mem-

\footnotetext{
5 Article 207(1) of the Treaty on the Functioning of the EU (TFEU). Consolidated Version of the Treaty on European Union [2008] OJ C115/13.

6 '[Bilateral] Free Trade Agreements (FTAs), if approached with care, can build on WTO and other international rules by going further and faster in promoting openness and integration, by tackling issues which are not ready for multilateral discussion and by preparing the ground for the next level of multilateral liberalisation. Many key issues, including investment, public procurement, competition, other regulatory issues and IPR enforcement, which remain outside the WTO at this time, can be addressed through FTAs. [...] We should continue to factor other issues and the wider role of trade policy in EU external relations into bilateral trade developments. [...] In terms of content new competitiveness-driven FTAs would need to be comprehensive and ambitious in coverage, aiming at the highest possible degree of trade liberalisation including far-reaching liberalisation of services and investment. [...] FTAs should also tackle non-tariff barriers through regulatory convergence wherever possible and contain strong trade facilitation provisions. FTAs should include stronger provisions for IPR and competition. [...] In considering new FTAs, we will need to work to strengthen sustainable development through our bilateral trade relations. This could include incorporating new co-operative provisions in areas relating to labour standards and environmental protection.' Commission, 'Global Europe, Competing in the World' (2006) $10-12$.
}

7 Marise Cremona, 'Shaping EU Trade Policy post-Lisbon: Opinion 2/15 of 16 May 2017' (2018) 14(1) European Constitutional Law Review 2.

8 Daniela Vincenti, 'EU, Canada Change ISDS Clause, Get Closer to "Gold-plated Trade Deal”', Euractiv (29 February 2016). 
ber States' governments lose the right to veto, and the same applies de facto to their national (and regional) parliaments if they are involved in the ratification of international agreements.

The role of national parliaments in making trade policy has traditionally been marginal. Negotiations, which are typically highly technical, were left for the Commission which consulted regularly with governments. National parliaments never challenged the adoption of FTAs. This practice changed during the TTIP debate when national parliaments became increasingly engaged in the $\mathrm{CCP} .{ }^{9}$ Questions regarding the legitimacy of the EU's approach to exclusive competence over trade policy became louder in the public discourse. For example, on 25 June 2014, sixteen chambers of Member States' national parliaments issued a letter to the then trade commissioner Karel de Gucht setting out the case for the mixity of the CETA and the TTIP and gave 'great importance' to ratification by national parliaments. ${ }^{10}$ Parliaments' engagement grew from indifference to assertion. There can be no doubt that this development influenced the position of the Member States' governments in the Council in the end-phase of the CETA talks. ${ }^{11}$

It thus came as no surprise when the Council strongly disagreed with the legal analysis presented by the Commission in its draft proposals for signature and ratification of the CETA as an exclusive agreement. For several months, the Council and the Commission debated the legal nature of the CETA and the scope of the respective competences of the Members States and the Union. Frustrated, Trade Commissioner Cecilia Malmström admitted after several meetings that the political situation in the Council is clear, and we understand the need for proposing it as a mixed agreement requiring Member States be party to the agreement, in order to allow for a speedy signature. ${ }^{2}$

9 Christilly Roederer-Rynning, Morten Kallestrup, 'National Parliaments and the New Contentiousness of Trade' (2017) 39(7) Journal of European Integration 815.

10 Commissie Europese Zaken, 'Letter in the Framework of the Political Dialogue: The Role of National Parliaments in Free Trade Agreements' (25 June 2014) <www.ipex.eu/ IPEXL-WEB/scrutiny/COM20140153/huors.do > accessed 28 June 2018.

11 For instance, Germany's Chancellor Angela Merkel declared that '[t]he participatory rights of the German Bundestag allow that we, as the federal government, will, of course, involve the Bundestag. The parliamentary vote will play an important role in the German voting behaviour in Brussels'. Die Bundesregierung, 'Freihandelsabkommen CETA. Merkel: Bundestag muss mitstimmen' (30 June 2016) <www.bundesregierung.de/Content/ DE/Artikel/2016/06/2016-06-29-merkel-will-bei-ceta-bundestag-mitreden-lassen.html $\geq$ accessed 28 June 2018.

12 Commission, 'European Commission Proposes Signature and Conclusion of EU-Canada Trade Deal' (5 July 2016) <http://trade.ec.europa.eu/doclib/press/index.cfm?id=1524 $\geq$ accessed 5 April 2018. 
Mixity in practice meant an approval initially by the Council, and the European Parliament, but also unanimously by the 38 national and regional parliaments. ${ }^{13}$ The necessary national ratification process brought risks of the treaty being blocked by national and regional parliamentary objections or referendums with a veto-right for each Member State, effectively nullifying the qualified majority voting in the Council. ${ }^{14}$

The Commission found itself between a rock and a hard place. While the mixed nature of the CETA would have satisfied the Member States, it would also have the potential to backfire almost immediately with serious consequences for the CCP. First, Bulgaria and Romania had made it clear they would veto the CETA because of the failure by Canada to lift the visa requirement for their nationals. Next, the CETA was reviewed by the German Federal Constitutional Court on a request for temporary legal protection. ${ }^{15}$ The final and most serious obstacle was the Walloon parliament, a regional legislature in Belgium, which threatened to block the entire agreement because, under Belgium's constitutional system, all seven regional and communal parliaments ${ }^{16}$ must give their consent to the federal government to sign an international treaty. After additional concessions and the last-minute-annexed Joint Interpretative Instrument, ${ }^{17}$ the Commission was able to ensure that the path towards signature of the CETA could continue.

The CETA was finally signed at the EU-Canada Summit on 30 October 2016. However, the writing was now on the wall for the Commission's

13 David A Gantz, 'The CETA Ratification Saga: The Demise of ISDS in EU Trade Agreements?' (2017) 40(2) Loyola University Chicago Law Journal 362.

14 Guillaume Van Der Loo, Ramses A Wessel, 'The Non-Ratification of Mixed Agreements: Legal Consequences and Solutions' (2017) 54(3) Common Market Law Review 738.

15 BVerfG, Judgment of the Second Senate of 13 Oct 2016 - 2 BvR ECLI:DE:BVerfG:2016. See also Andreas Schöpgens and Geert Van Calster, 'Multilevel Constitutional Review and EU External Treaty Making After Opinion 2/15' (2018) 23(4) European Foreign Affairs Review 439.

16 Regions: Flanders, Wallonia, Brussels-Capital; Communities: French Community, German-speaking Community, French Community Commission, Common Community Commission.

17 Joint Interpretative Instrument on the Comprehensive Economic and Trade Agreement (CETA) between Canada and the European Union and its Member States [2017] OJ L11/3. Part of the final compromise included the Belgium Government's commitment to submit the investment court system to the CJEU as officially declared in the statement by the Kingdom of Belgium entered in the Council minutes: 'Belgium will ask the European Court of Justice for an opinion on the compatibility of the ICS with the European treaties, in particular in the light of Opinion A-2/15'. Council of the EU, 'Council Decision (EU) 2017/37 of 28 October 2016 on the signing on behalf of the European Union of the Comprehensive Economic and Trade Agreement (CETA) between Canada, of the one part, and the European Union and its Member States, of the other part'. 
approach. The ability of a regional parliament representing less than $1 \%$ of the EU population to significantly hinder the progress of the agreement ${ }^{18}$ should have been understood as the final warning that the EU was about to lose its ability to act to conclude FTAs. ${ }^{19}$

\section{The Court's opinion on the EU-Singapore FTA and mixity}

The Lisbon Treaty does not provide precise contours of the scope of the CCP. Crucially, the Lisbon Treaty does not define foreign direct investment or intellectual property. It is also ambiguous on transport services and the relationship between trade, transparency and sustainable development. This has led to numerous competence disputes between the Commission and the Council ${ }^{20}$ and, finally, to the Court's clarification in Opinion 2/15. In this sense, Opinion $2 / 15$ was 'of such great relevance' because it 'define[s] the limits of the common commercial policy, and determine[s] whether the latest Treaty reforms tell the tale of the EU's empowerment in international trade and investment policy, or rather that of inevitable mixity'. ${ }^{21}$

The Court proceedings in this case were initiated by the Commission on 10 July 2015. To determine the legal nature of the EUSFTA and to avoid another CETA scenario, the Commission posed the following question to the CJEU:

\footnotetext{
18 Wallonia together with Brussels has a population of $1.8 \mathrm{~m}$ to the EU's approximately $510 \mathrm{~m}$.

19 David Kleimann and Gesa Kübek, "After the "CETA Drama", Toward a More Democratic EU Trade Policy' (Politico, 12 January 2016) <www.politico.eu/article/opinion-after-the-ceta-drama-toward-a-more-democratic-eu-trade-policy/> accessed 12 April 2018. Concerns associated with mixity were also recognised by Advocate-General Sharpston in her opinion: 'A ratification process involving all the Member States alongside the European Union is of necessity likely to be both cumbersome and complex. It may also involve the risk that the outcome of lengthy negotiations may be blocked by a few Member States or even by a single Member State. That might undermine the efficiency of EU external action and have negative consequences for the European Union's relations with the third State(s) concerned'. Case A-2/15 Singapore FTA ECLI:EU:C:2016:992, Opinion of AG Sharpston, para 565.

20 See eg Case C-414/11 Daiichi Sankyo and Sanofi-Aventis Deutschland ECLI:EU:C:2013:520 concerning intellectual property rights contained in the TRIPs Agreement or different positions of the European Commission and the Council regarding non-direct investment and ISDS: compare the European Commission's draft regulation on financial responsibility and the final version 'Regulation (EU) No 912/2014 of the European Parliament and of the Council of 23 July 2014 establishing a framework for managing financial responsibility linked to investor-to-state dispute settlement tribunals established by international agreements to which the European Union is party'.

${ }^{21}$ Hannes Lenk, 'Mixity in EU Foreign Trade Policy Is Here to Stay: Advocate General Sharpston on the Allocation of Competence for the Conclusion of the EU-Singapore Free Trade Agreement' (2017) 2(1) European Papers 6.
} 
Does the Union have the requisite competence to sign and conclude alone the Free Trade Agreement with Singapore? More specifically,

1. which provisions of the agreement fall within the Union's exclusive competence?

2. which provisions of the agreement fall within the Union's shared competence? and

3. is there any provision of the agreement that falls within the exclusive competence of the Member States? ${ }^{22}$

The Commission, supported by the European Parliament, argued that all the provisions of the agreement fell within the exclusive competence of the Union and had to be concluded by the Union alone. Conversely, the Council and 26 Member States argued that the agreement did not just cover exclusive competence and should be concluded as a mixed agreement.

The resulting Opinion of the Court was issued 22 months later on 16 May 2017. It covers a number of areas of the EUSFTA as well as the general issues related to the relationship between the EU and the Member States on matters of trade and investment: (1) Trade in goods; (2) Trade in services other than transport; (3) Transport services; (4) Government procurement; (5) Intellectual property; (6) Competition law; (7) Trade and sustainable development; (8) Investment; (9) Bilateral investments treaties between the Member States and Singapore; and (10) Competence to approve the institutional provisions of the envisaged agreement.

The Court identified only two substantive areas of shared competence in the EUSFTA: non-direct forms of investments and investor-state dispute settlement. The Court found that the rest of the agreement fell within the Union's exclusive competence. In contrast, Advocate-General Sharpston came to a different conclusion. In her opinion, the EU shared with Member States competence over transport services (and related government procurement), portfolio investment, ISDS, non-commercial aspects of intellectual property rights and some part of the sustainable development chapter with related provisions in the transparency, institutional and final chapters. Moreover, she even identified an exclusive competence of Member States in a provision regulating the termination of Member States' bilateral investment agreements concluded with Singapore. $^{23}$

22 Opinion A-2/15 Singapore FTA ECLI:EU:C:2017:376.

23 Opinion A-2/15, Opinion of AG Sharpston (n 19). For detailed analyses of Sharpston's Opinion, see Lenk (n 21). 
For its conclusion, the Court mostly relied on its dictum in the Daiichi case ch $^{24}$ to apply a 'specific link test' to determine whether a particular provision of the Singapore FTA falls within the scope of Article 207 of the Treaty on the Functioning of the European Union (TFEU):

36. It is settled case-law that the mere fact that an EU act, such as an agreement concluded by it, is liable to have implications for trade with one or more third States is not enough for it to be concluded that the act must be classified as falling within the common commercial policy. On the other hand, an EU act falls within that policy if it relates specifically to such trade in that it is essentially intended to promote, facilitate or govern such trade and has direct and immediate effects on it [...].

37. It follows that only the components of the envisaged agreement that display a specific link, in the above sense, with trade between the European Union and the Republic of Singapore fall within the field of the common commercial policy. ${ }^{25}$

The Court applied this test in the Opinion and, as a result, the broad understanding of the scope of Article 207 TFEU has been confirmed in line with previous case law applying a dynamic interpretation of the scope of the CCP. ${ }^{26}$ Beyond traditional areas of the CCP such as trade in goods and services other than transport, exclusive competence was found in the chapters on government procurement, competition, and perhaps surprisingly transport services and intellectual property. On transport services, the Court accepted that the fields of maritime, rail and road transport are already largely covered by Union legislation employing a very low threshold when a policy field is considered to be largely covered. ${ }^{27}$ Regarding internal waterway transport, the Court did not refer to any EU legislation. However, due to the marginal scope of this field, the EU has the exclusive competence in respect of this chapter in its entirety. ${ }^{28}$ In the case of intellectual property, it is reaffirmed by previous case law $^{29}$ that its commercial aspects fall within the scope of the CCP. Nevertheless and notably, the Court's assessment of reference to multilateral conventions which include a provision relating to moral rights as of an exclusive nature goes beyond an established scope. ${ }^{30}$ For

\footnotetext{
${ }^{24}$ Daiichi Sankyo (n 20) paras 51-52. See also Case C-137/12 Commission v Council ECLI:EU:C:2013:675, para 57; Opinion A-3/15 Marrakesh Treaty on access to published works ECLI:EU:C:2017:114, para 61.

25 Opinion A-2/15 (n 22) paras 36-37.

26 See eg Opinion 1/75 Local Cost Standard ECLI:EU:C:1975:145, 1361; Opinion 1/78 Natural Rubber ECR 2871, para 44.

27 Opinion A-2/15 (n 22), para 180.

28 ibid, paras 216-217.

29 Daiichi Sankyo (n 20).

30 Opinion A-2/15 (n 22) para 129.
} 
the purposes of this paper, it suffices to further analyse two parts of the decision, investment protection and sustainable development, together with broader implications for mixity in EU agreements.

\subsection{Investment protection}

The Court's findings on the market access implications of the investment chapter in EUSFTA are largely uncontroversial. The Court started its examination of investment protection by pointing out that the investment chapter in EUSFTA relates both to direct investment and to any other type of investment. ${ }^{31}$ The Court repeated its own definition of foreign direct investment (FDI) as 'investments of any kind made by natural or legal persons which serve to establish or maintain lasting and direct links between the persons providing the capital and the undertakings to which that capital is made available in order to carry out an economic activity'. ${ }^{32}$ Subsequently, it applied this definition to FDI in Article 207 TFEU with the unsurprising conclusion that the Union has exclusive competence in this area. ${ }^{33}$ It has always been understood by the Commission as well as the Council that the scope of the CCP covers market access and the promotion of FDI. ${ }^{34}$

It was the post-establishment protections in EUSFTA - including the substantive investor protection and ISDS - that was the root of the fiercest disagreements between the Council and the Commission. Importantly, the Court pointed out that the competence to conclude agreements on foreign direct investment includes rules on the protection of existing investments. ${ }^{35}$ The Court then discussed the relevant clauses of the investment chapter and found that this framework 'is intended to promote, facilitate and govern trade between the European Union and the Republic of Singapore, within the meaning of [the Daiichi case law]'. This is supported by the Court's dictum 'direct and immediate effects on ... trade' to justify its decision. ${ }^{36}$

As regards investment other than FDI, the Opinion contains one of the most significant conclusions - the use of the term in Article 207 TFEU implies that the drafters of the Treaties did not intend to include other types of investment in the CCP. Accordingly, commitments vis-à-

\footnotetext{
31 ibid, para 79.

32 Case C-446/04 Test Claimants in the FII Group Litigation ECLI:EU:C:2006:774, paras 181-182; Case C-326/07 Commission v Italy ECLI:EU:C:2009:193, para 35.

33 Opinion A-2/15 (n 22) paras 80-82.

34 Lenk (n 21) 16.

35 Opinion A-2/15 (n 22) para 87.

36 Opinion A-2/15 (n 22) para 94.
} 
vis a third State relating to other foreign investment do not fall within the exclusive competence of the European Union pursuant to Article 3(1) (e) TFEU. ${ }^{37}$

This led to the question whether such other investment might still be an exclusive competence on the basis of the ERTA effect. The Commission had argued that Article 63 TFEU was itself a common rule that was affected by the Singapore FTA; therefore, according to the Commission, the ERTA effect of Article 3(2) TFEU implied that the EU had exclusive competence over indirect investment as well. By contrast, the Council had argued that, if indeed TFEU provisions were among the common rules that could be affected within the meaning of Article 3(2) TFEU, then the Treaty drafters could have written directly into the Treaty that the Union had exclusive external competence for capital movements. They did not do so. Moreover, Article 64(2) TFEU provides for a legal basis only for Union legislation on capital movements in the field of direct investments.

The Court dismissed the Commission's arguments, agreeing with the Council that the ERTA case law does not permit a provision of primary law to be the 'common rule' affected by the international agreement. The Court started by recalling that:

non-direct foreign investment may, inter alia, take place in the form of the acquisition of company securities with the intention of making a financial investment without any intention to influence the management and control of the undertaking ('portfolio' investments), and that such investments constitute movements of capital for the purposes of Article 63 TFEU. ${ }^{38}$

Furthermore, the Court reasoned that the primacy of the Treaties does not permit a secondary law act to have an impact on the meaning or scope of the Treaties' provisions. International agreements therefore cannot 'affect' rules of primary EU law or 'alter their scope' within the meaning of Article 3(2) TFEU. ${ }^{39}$ Since none of the other situations under this provision are fulfilled, the Court decided that the Union has no exclusive competence to conclude an agreement relating to the protection of non-direct foreign investments. ${ }^{40}$

The Court went on to find that the conclusion of agreements on non-direct investment may prove necessary in order to achieve, within the framework of the Union's policies, one of the objectives referred

\footnotetext{
37 ibid, para 83.

38 ibid, para 227.

39 ibid, para 235.

40 ibid, para 238.
} 
to in the Treaties. ${ }^{41}$ Since Article 63 TFEU - being an internal market provision - is a shared competence as per Article 4(1) and (2)(a) TFEU, the competence for such an agreement would be shared. This novel reasoning will undeniably raise some question in the future, particularly in light of the fact that neither Article 4 TFEU, nor Article 63 TFEU, nor Article 64 TFEU provide for competence for the Union to legislate in the field of portfolio investment.

Regarding ISDS, the Court found the mechanism to be under shared competence, because it 'removes disputes from the jurisdiction of the courts of the Member States'. ${ }^{42}$ By acknowledging the competence of the Member States in the area of ISDS, it is likely that the Court would apply the same finding in the case of other investment dispute settlement mechanisms proposed by the EU: that is, a system of investment court (ICS) and a multilateral investment court (MIC).

\subsection{Sustainable development}

Regarding the chapter regulating sustainable development issues, the question was whether this chapter could be concluded under the EU exclusive competences governing the CCP. The Court started its discussion of the sustainable development chapter by recalling that the EUSFTA is a 'new generation' trade agreement, 'that is to say, a trade agreement including ... other aspects that are relevant, or even essential, to ... trade..$^{43}$ The Court then pointed out that the Treaty of Lisbon considerably amended the CCP. It stressed the second sentence of Article 207(1) TFEU: 'The common commercial policy shall be conducted in the context of the principles and objectives of the Union's external action'. The principles and objectives of the EU's external action are spelled out in Article 21 of the Treaty of the European Union (TEU). Paragraph (2)(f) of that Article tasks the Union with 'help[ing] develop international measures to preserve and improve the quality of the environment and the sustainable management of global natural resources, in order to ensure sustainable development'.

The Court, referring to Articles 21(3) of the Treaty on European Union (TEU), 205 and 207 TFEU, subsequently concluded that the Union is obliged to integrate these objectives and principles into its $\mathrm{CCP}^{44}$ In addition, the Court referred to Articles 9 and 11 TFEU, which require the integration of social and environmental requirements in all Union poli-

\footnotetext{
41 Opinion A-2/15 (n 22) paras 239-242.

42 ibid, para 292.

43 ibid, para 140.

44 ibid, para 143.
} 
cies. The Court concluded that 'the objective of sustainable development henceforth forms an integral part of the common commercial policy'. ${ }^{45}$

The Council, which argued that all sustainable development provisions are not part of the CCP, had pointed out that part of the International Labour Organization (ILO) Conventions covered by Article 13.3(3) of the Agreement involves matters for which the Union explicitly has no competence. For example, Article 153(5) TFEU explicitly excludes any competence on, among other things, the right of association of workers. The Court dealt with this argument by finding that the EUSFTA just refers to such agreements without any implications to their scope or division of competence. In addition, the Court applied again its Daiichi 'direct and immediate effects on ... trade' test. ${ }^{46}$ On this basis, it finds that the sustainable development chapter falls within the scope of Article 207 TFEU.

One commentator noted that the 'answer of the Court was a resounding yes in favour of the EU exclusive competence on sustainable development [...] ${ }^{47}$ Nevertheless, we must be aware of the limitations of extensive interpretation by joint bodies established by the Parties or adopting a more ambitious approach in other negotiations.

\subsection{Multiple faces of mixity}

Summarising the whole Opinion, the Court found that most of the EUSFTA falls within the exclusive competence of the Union, but portfolio investment, ISDS and related ancillary provisions that fall within the competence shared between the Union and the Member States, ${ }^{48}$ under which the agreement could not be approved 'by the European Union alone'. ${ }^{49}$ Did this formulation mean the end of 'facultative mixity' in the sense that the EU could also conclude an agreement covered by shared competences alone if the Council so decides? The Court provided a clarification shortly after Opinion 2/15. In the COTIF judgment, the Court made it clear that the Council can still agree that mixity is not required and an agreement is so concluded only by the EU alone, without the participation of the Member States. ${ }^{50}$

\footnotetext{
45 ibid, para 147.

46 Opinion A-2/15 (n 22) paras 155, 157-161.

47 Giovanni Gruni, 'Towards a Sustainable World Trade Law? The Commercial Policy of the European Union After Opinion 2/15 CJEU' (2018) 12(1) Global Trade and Customs Journal 5.

48 Opinion A-2/15 (n 22) para 305.

49 ibid, paras 244, 282, 304.

50 Case C-600/14 Council v Germany (OTIF) ECLI:EC:C:2017:935, para 68.
} 
However, this possibility in fact does not change much in the context of investment protection. First, the likelihood of consensus among the Member States to let the EU conclude such an agreement alone is for numerous political reasons low, almost impossible. ${ }^{51}$ Second, facultative mixity is excluded in the case of ISDS or a comparable mechanism, as it removes disputes from the jurisdiction of the courts of the Member States. The right of the claimant investor to submit a dispute to ISDS under an agreement, without Member States being able to oppose this, takes a dispute away from their domestic courts. For the Court itself, such a mechanism 'cannot, therefore, be established without the Member States' consent'. ${ }^{52}$ The Court's explicit request for Member States' consent leads to the conclusion that there is not even a hypothetical option for the Council to decide whether an FTA with an investment chapter or an investment agreement covering any form of investor-state dispute settlement could be concluded by the EU alone. ${ }^{53}$ In the case of ISDS, ICS or MIC, 'mandatory mixity' will thus apply. Needless to say, investment protection provided for investors is significantly weaker without an effective dispute settlement system.

The implications of the Court's recent findings in Opinion 2/15 for the treatment of investment protection, ISDS and sustainable development in relation to other EU agreements need careful consideration. In fact, the Court's Opinion constitutes a strong precedent for future negotiations because EU FTAs have a similar structure. The Opinion invited the EU to reconsider an architecture of pending and future FTAs between the EU and Singapore, Vietnam, Japan, India, and Indonesia, among others, with legal implications for their following ratification procedure with respect to the division of competences.

\section{Shaping post-Lisbon Common Commercial Policy 2.0}

\subsection{New architecture adopted in the light of Opinion 2/15}

When planning the scope of FTAs, policymakers must consider their purpose and the context within which the envisaged treaties are negotiated. Governments should set priorities and have realistic expectations about the policies that will emerge from negotiations. Under the current conditions of change in global trade and investment flows and

\footnotetext{
51 Szilárd Gáspár-Szilágyi, ‘Quo Vadis EU Investment Law and Policy? The Shaky path Towards the International Promotion of EU Rules' (2018) 23(2) European Foreign Affairs Law 184.

52 Opinion A-2/15 (n 22) para 292.

53 Luca Prete, 'Some Thoughts on Facultative and Obligatory Mixity after Singapore and COTIF, and before CETA' (18 October 2018) VerfBlog.
} 
the deepening of economic globalisation that have led to closer linkages between trade and investment, governments have increasingly reflected this trend in negotiating comprehensive FTAs.

It was NAFTA's investment chapter which in 1994 signalled a new era where investment issues are addressed in comprehensive FTAs. According to a recent study, investment provisions are part of 450 FTAs in force today. ${ }^{54}$ Another empirical study confirms a rising tendency of including investment chapters in FTAs. ${ }^{55}$ There is a growing corpus of studies arguing for the increasing convergence of trade and investment law creating normative coherence. ${ }^{56}$ Some of these studies even characterise the current situation where still only a handful of FTAs cover both trade and investment as an artificial separation between the regimes. ${ }^{57}$

These views are supported by an expansion of global value chains. FDI can stimulate positive spillovers, while investments have crucial importance in the creation and expansion of productive supply capacities. ${ }^{58}$ It is undeniable that the expansion of global value chains over the past decades has changed patterns of trade and FDI, and rendered them more complex and inter-dependent. Global value chains go beyond trade and investment policies and involve other policy areas, such as competition policy, intellectual property rights, standards and data flows. There is a broad scope of provisions relevant for the operations of multinational enterprises and this is reflected in recent complex FTAs that have chapters addressing a variety of policy issues. Besides, due to some commonalities and overlapping aspects among the regimes, it seems natural to situate both systems of laws in FTAs. ${ }^{59}$ The operations of foreign investors have become more sophisticated and their investments are always

54 Wolfgang Alschner, 'The Investment Component in Trade Agreements' in Robert Looney (ed), Routledge Handbook in International Trade Agreements (Routledge 2018) 79.

55 Maksim Usyninm and Szilárd Gáspár-Szilágyi, 'The Growing Tendency of Including Investment Chapters in PTAs' in F Amtenbrink and others (eds), Netherlands Yearbook of International Law 2017 (TMC Asser Press 2018) 288.

56 Tomer Broude, 'Investment and Trade: The "Lottie and Lisa" of International Economic Law?' in Roberto Echandi and Pierre Sauvé (eds), Prospects in International Investment Law and Policy (CUP 2013); Gary Hufbauer and Tyler Moran, Investment and Trade Regimes Conjoined: Economic Facts and Regulatory Frameworks (International Centre for Trade and Sustainable Development 2015); Jürgen Kurtz, The WTO and International Investment Law: Converging Systems (CUP 2016).

57 Eg Gary Hufbauer and Gary Clyde, 'Rules of the International Trade, Investment, and Financial Systems: What They Deliver, How They Differ, the Way Forward' (2014) 17(4) Journal of International Economic Law 833.

58 UNCTAD, 'Trade and Development Report 2013' (United Nations 2013) 87.

59 For an opposite view, see eg Simon Lester, 'Lessons from Europe for US Trade Policy: Is It Time to Separate Trade Liberalization and Investment Protection?' (Huffington Post, 21 September 2017) <www.huffingtonpost.com/entry/lessons-from-europe-for-us-tradepolicy-is-it-time_us_59c10df7e4b0f96732cbc8fe> accessed 6 March 2018. 
combined with other types of relationships. It is not only trade and investment liberalisation that is complementary, but a broader set of behind-the-border regulations. The prime example of this development is the recently signed and provisionally applied CETA, frequently described as a 'deep and comprehensive' FTA with regard to its content. In addition, expanded competence in the Lisbon treaty allowed the Union to be at the forefront of the development of international investment law and policy. ${ }^{60}$

Nevertheless, the inclusion of investment provisions in FTAs is among the most contested issues at a time when trade liberalisation is facing growing domestic opposition. Many policymakers in the EU can have the feeling that their life may be much easier due to simplified ratification without investment protection and ISDS being covered. The CIEU's Opinion 2/15 rose to the expectation of a departure from the practice of mixed EU FTAs. By decoupling investment chapters from FTAs, the EU could conclude trade agreements by itself, without the Member States. Accordingly, such EU-only negotiations and the signature and conclusion of FTAs would reduce the amount of veto-rights and minimise the transaction costs of trade governance. ${ }^{61}$ Finally, the investment chapter risks protracting negotiations or compromising the whole agreement

In alignment with this approach, the Commission already in autumn 2017 admitted that 'the debate on the best architecture for EU trade agreements and investment protection agreements must be completed'. In the same breath, it stressed that 'the EU must be a credible negotiating partner: our institutional decision-making must be clear, predictable and fit for purpose'. ${ }^{62}$ Accordingly, the state of thinking in the Commission could have been easily foreseen. The splitting of FTAs was subsequently adopted in the Council's conclusions on the negotiation and conclusion of FTAs in May $2018^{63}$ and the new practice is taking place in current and upcoming negotiations in which the investment part will be segregated from the rest of the provisions.

The conclusions now set out the Council's key principles towards trade and investment negotiations with a focus on distinguishing be-

\footnotetext{
60 Federico Ortino and Piet Eeckhout, 'Towards an EU Policy on Foreign Direct Investment' in Andrea Biondi, Piet Eeckhout and Stefanie Ripley (eds), EU Law after Lisbon (OUP 2012) 327.

61 David Kleimann, 'Beyond the Shadow of the Veto: Economic Treaty-Making in the European Union after Opinion 2/15' in Elaine Fahey (ed), Institutionalisation Beyond the Nation State (Springer 2018) 166.

62 Commission, 'A Balanced and Progressive Trade Policy to Harness Globalisation' (13 September 2017) 6 .

63 Council of the European Union, 'Outcome of the Outcome Meeting, 3618th Council meeting' (22 May 2018) <www.consilium.europa.eu/media/34837/st09102-en18.pdf $\geq$ accessed 2 June 2018.
} 
tween separate provisions related to investment and other trade provisions. In other words, the EU itself will conclude the main trade agreement while a separate side investment treaty will be subject to ratification in all Member States. The CETA saga played an important role as a 'wake-up call'. Several authors considered the Commission's acceptance of the mixed nature of the CETA as regaining some trade competences. ${ }^{64}$ But Opinion 2/15 and the subsequent development neutralised this advantage of the Council over the Commission. The apparent risk that the EU might become incapable of concluding FTAs in the future and also might lose credibility with its partners forced Member States to give up mixity and the unanimity rule. Given this, the Council conclusions have significant ramifications for the CCP.

Evidence of this new approach is already observed in several recently concluded and ongoing negotiations. The EUSFTA, as the direct subject of Opinion 2/15, first reflected this new architecture. On 18 April 2018, the Commission presented to the Council the result of the EUSFTA and divided the original agreement into two new agreements: the EU-Singapore Trade Agreement and the EU-Singapore Investment Protection Agreement (IPA). ${ }^{65}$ The initially negotiated text for a comprehensive FTA with Vietnam followed the pattern of the EUSFTA to create two self-standing agreements: the EU-Vietnam Free Trade Agreement under EU-exclusive competence, and the EU-Vietnam Investment Protection Agreement under mixed competence. ${ }^{66}$

Similar developments took place with regard to EU negotiations with Japan, Australia and New Zealand. In the case of Japan, an agreement in principle on the EU-Japan Economic Partnership Agreement (EPA) was reached on 7 July 2017. Nevertheless, Japan has openly opposed the EU reform approach in investment protection and investment dispute settlement. ${ }^{67}$ The investment part was then pragmatically separated due

${ }_{64}$ Kurt Hübner, Anne-Sophie Deman and Tugce Balik, 'EU and Trade Policy-making: The Contentious Case of CETA' (2017) 39(7) Journal of European Integration 851.

65 Commission, 'Press Release: Key Elements of the EU-Singapore Trade and Investment Agreements' (18 April 2018) <http://trade.ec.europa.eu/doclib/press/index.cfm?id=1827 $\geq$ accessed 3 March 2018.

66 Commission, 'Commission Presents EU-Vietnam Trade and Investment Agreements for Signature and Conclusion' (17 October 2018) <http://trade.ec.europa.eu/doclib/press/ index.cfm?id=1921 $>$ accessed 25 December 2018.

67 See, eg, Anthea Roberts, 'UNCITRAL and ISDS Reform: Pluralism and the Plurilateral Investment Court', EJIL: Talk! (12 December 2017) <www.ejiltalk.org/uncitral-and-isds-reform-pluralism-and-the-plurilateral-investment-court/ $\geq$ accessed 11 April 2018. The Japanese negative stance is likely the result of a combination of several causes. Japan has never faced an investment claim and, with regard to the level of the rule of law in the Member States of the EU, there is no strong motivation for Japanese companies to push investment protection in the negotiations. In addition, the Japanese government faced a hard-fought 
to these irreconcilable differences between the two sides in order not to delay the approval of the entire FTA. In this regard, the decision has been vindicated, as the EPA between the EU and Japan entered into force on 1 February 2019. Considering Australia and New Zealand, the Commission submitted draft directives for negotiations to the Council in September 2019. The draft mandates do not include an investment part and they are thus limited to substance covered by the EU exclusive competence. ${ }^{68}$ In this regard, the directives were also approved by the Council. ${ }^{69}$ What is important is that the other crucial European institution, the European Parliament, expressed support for this approach stated in its resolution for trade negotiations with Australia (and identically with New Zealand):

on the Commission and the Council to put forward a proposal as soon as possible about the general future architecture of trade agreements taking into account CJEU Opinion 2/15 on the EU-Singapore FTA, and to clearly distinguish between a trade and liberalisation of foreign direct investment (FDI) agreement, containing only issues that fall within the EU's exclusive competence, and a potential second agreement which covers subjects whose competences are shared with Member States. ${ }^{70}$

It should be recalled that this approach is not entirely new because the EU has already pursued investment liberalisation through both FTAs and stand-alone investment agreements. ${ }^{71}$ Still, the EU investment policy reliant only on investment treaties cannot use the potential leverage provided by being a part of an FTA. Comprehensive trade and investment agreements allow for more far-reaching 'package deals' and quid pro quo compromises across various chapters. ${ }^{72}$ In the context of the EU, it may

battle and invested much political capital to persuade the public and lawmakers to accept ISDS in the TPP.

68 Commission, 'Annex to the Recommendation for a Council Decision Authorising the Opening of Negotiations for a Free Trade Agreement with Australia' (13 September 2017); Commission, 'Annex to the Recommendation for a Council Decision Authorising the Opening of Negotiations for a Free Trade Agreement with New Zealand' (13 September 2017).

69 Council of the European Union, 'Negotiating Directives for a Free Trade Agreement with Australia' (25 June 2018); Council of the European Union, 'Negotiating Directives for a Free Trade Agreement with New Zealand' (25 June 2018).

70 European Parliament, 'Resolution of 26 October 2017 Containing the Parliament's Recommendation to the Council on the Proposed Negotiating Mandate for Trade Negotiations with Australia' (2017) para 10.

71 Eg investment negotiations with China, see Commission, 'Press Release: EU and China Begin Investment Talks' (20 January 2014) <http://trade.ec.europa.eu/doclib/press/ index.cfm?id=1013\&title=EU-and-China-begin-investment-talks $>$ accessed 19 May 2018.

72 Steffen Hindelang, Jurgita Baur and Stephan Schill, 'EU Investment Protection after the ECJ Opinion on Singapore: Questions of Competence and Coherence. Study Requested by the INTA Committee. Policy', Department for External Relations of the European Parliament (25 March 2019) 23. 
also use its market size to assert forcefully specific goals in negotiations. Saying this, it is necessary to highlight that in order to pursue its ambitious reform goals, ${ }^{73}$ including the establishment of a multilateral investment court, it is essential for the EU to be able to use any leverage. As a consequence, for the purposes of promoting its new approach, the EU investment policy has likely suffered a serious blow as a result of the policy decision. ${ }^{74}$ Without the leverage of the rest of the FTAs, the Commission's negotiators face a more challenging task to persuade its partners to adopt the EU reform proposals, regardless of other factors, such as market size, the previous trade and investment relationship with a third country, and its own developed treaty policy.

As the public consultation on investment protection and ISDS in the TTIP showed, ${ }^{75}$ the Commission has struggled to find continuity while putting together a common investment policy acceptable for a broad spectrum of domestic stakeholders. Moreover, in its recent Opinion $1 / 17,{ }^{76}$ the Court not only ruled on the compatibility of CETA's investment chapter with EU law, but set conditions for the future investment rules in EU agreements. ${ }^{77}$ Now, there is an increasing risk that the EU proposals will become unacceptable for a number of third countries. This may undermine the widely shared perception that the new competence in the Lisbon treaty allows the Union to be at the forefront of the development of international investment law and policy. ${ }^{78}$

\footnotetext{
73 In the 'Trade for All' strategy, the European Commission declared that the EU is best placed and has special responsibility in the reform of the global investment regime 'as its founder and main actor'.

74 Elsa Sardinha, 'The New EU-Led Approach to Investor-State Arbitration: The Investment in the Comprehensive Economic Trade Agreement (CETA) and the EU-Vietnam Free Trade Agreement' (2017) 32(3) ICSID Review 627. Similarly, speaking of 'undermining the EU's role as powerful driver of reform in international investment law' see Philip Hainbach, 'The CJEU's Opinion 2/15 and the Future of EU Investment Policy and Law-Making' (2018) 45(2) Legal Issues of Economic Integration 200.

75 For more information, see Ondřej Svoboda, 'TTIP and ISDS: Not Irreconcilable Acronyms' (2015) 6 Czech Yearbook of Public \& Private International Law 352.

76 Opinion A-1/17 CETA ECLI:EU:C:2019:341.

77 Marc Bungenberg and Catharine Titi, 'CETA Opinion-Setting Conditions for the Future of ISDS', EJIL: Talk! (5 June 2019) <https://www.ejiltalk.org/ceta-opinion-settingconditions-for-the-future-of-isds/> accessed 18 July 2019.

78 Ortino and Eeckhout (n 60) 327.
} 


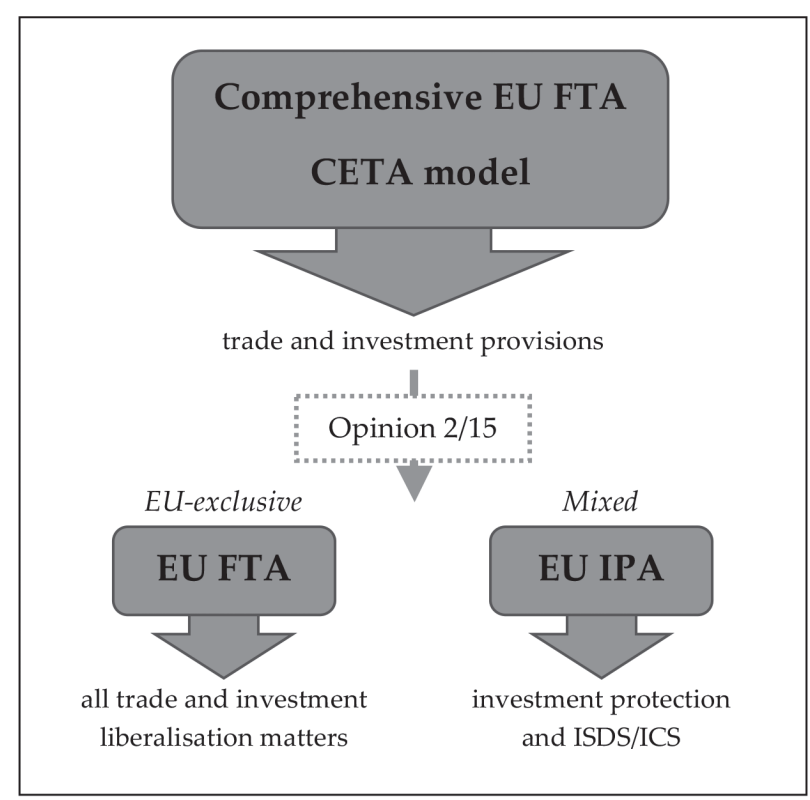

Scheme of the new EU FTA architecture

\subsection{Coupling investment protection and sustainable development: an alternative path}

The approach adopted by the Commission and the Council after Opinion 2/15 is logical. However, one may feel that EU policymakers could be more innovative and ambitious in considering the next steps. While decoupling investment protection from trade issues for the sake of the exclusivity of trade agreements is understandable, the Court's reasoning also has important implications for trade policymakers in the field of sustainable development, which may not be apparent at first blush.

FTAs' salience in addressing non-economic concerns such as protection of the environment and labour standards has been frequently criticised by politicians, trade unions and civil society. The Commission's communication 'Trade for All' reflected this trend, recognising the importance of this issue for many EU citizens, 'with many asking whether it [the trade policy] is designed to support broad European interests and principles or the narrow objectives of large firms' ${ }^{79}$ To recognise the increasing concerns of citizens about social and environmental conditions in the countries the EU trades with has certainly been a step in the right direction. ${ }^{80}$

\footnotetext{
79 Commission, 'Trade for All - Towards a More Responsible Trade and Investment Policy' (14 October 2015) 18.

80 Ricard Bellera i Kirchhoff, 'Trade for Fairness' in Patricia Garcia-Duran and Montserrat Millet (eds), Different Glances at EU Trade Policy (CIDOB 2016) 48.
} 
Following Opinion 2/15, the Commission has had the opportunity to be bolder, as the EU exclusive competence in this field is no longer disputed under current drafting. As a result of the Court's reasoning, broader sustainable development could be construed as an integral and effective part of the CCP, which is often criticised for disregarding socio-environmental concerns and favouring business at the expense of public interests. Despite the EU negotiating sustainable development provisions in its trade agreements since the 1990s, the result of this effort has been considered disappointing and has given rise to the question of how the trade and sustainable development (TSD) chapters can be strengthened. ${ }^{81}$

The internal considerations have already been initiated. The first sign of this direction is the re-emerged debate on the dispute settlement mechanism for the TSD chapters that could include state-to-state consultation and dispute mechanisms, as well as the means to the easier participation of civil society. ${ }^{82}$ The Commission has recently committed itself to promoting these improvements and pursuing the enforcement of the covered commitments in the TSD chapters under a 'more assertive approach, ${ }^{83}$ Other improvements can be implemented in drafting robust labour and environmental standards going beyond mere references to other international treaties or such general wording that is only of a declaratory nature. ${ }^{84}$ Also in this field, the European Parliament (which has repeatedly called for improvement here ${ }^{85}$ has already expressed its view in the context of the then approaching negotiations with Australia (and New Zealand):

[I]n view of CJEU Opinion 2/15 on the EU-Singapore FTA that trade and sustainable development fall within the EU's exclusive competence

\footnotetext{
81 For instance, one analysis found no evidence that the existence of EU TSD chapters has led to improvements in labour standards governance. See James Harrison and others, 'Governing Labour Standards through Free Trade Agreements: Limits of the European Union's Trade and Sustainable Development Chapters' (2019) 57(2) Journal of Common Market Studies 273.

82 Commission, 'Trade and Sustainable Development (TSD) Chapters in EU Free Trade Agreements (FTAs)' (11 July 2017) 7. See also Francesca Romain Jacur, 'Corporate Social Responsibility in Recent Bilateral and Regional Free Trade Agreements: An Early Assessment' (2018) 23(4) European Foreign Affairs Review 478-481; Kate ina Hradilová and Ond ej Svoboda, 'Sustainable Development Chapters in the EU Free Trade Agreements: Searching for Effectiveness' (2018) 52(6) Journal of World Trade 1019.

83 Commission, 'Non Paper of the Commission Services: Feedback and Way Forward on Improving the Implementation and Enforcement of Trade and Sustainable Development Chapters in EU Free Trade Agreements' (26 February 2018).

84 Gruni (n 47) 6.

85 See eg European Parliament, 'Resolution of 14 March 2019 on the Annual Strategic Report on the Implementation and Delivery of the Sustainable Development Goals (SDGs)' (2019) 25.
} 
and that sustainable development forms an integral part of the EU's common commercial policy, a robust and ambitious sustainable development chapter is an indispensable part of any potential agreement; provisions for effective tools for dialogue, monitoring and cooperation, including binding and enforceable provisions which are subject to suitable and effective dispute settlement mechanisms, and consider, among various enforcement methods, a sanctions-based mechanism, while enabling social partners and civil society to participate appropriately, as well as close cooperation with experts from relevant multilateral organisations. ${ }^{86}$

The new tendency to promote sustainable issues more forcefully is also evident in the first ever activation of a state-to-state dispute settlement mechanism under an EU trade and sustainable development chapter. At the end of 2018, the EU began government consultations with the Republic of Korea regarding the country's implementation of labour commitments related to the EU-Korea FTA. ${ }^{87}$ Almost at the same time, fundamental ILO Conventions were raised by the European Parliament in the context of the approaching signing of the EU-Vietnam FTA. ${ }^{8}$ With the new European Parliament, a stronger push for sustainability in the CCP is expected. ${ }^{89}$ The latest developments confirm this trend. Ursula von der Leyen, currently the President-elect of the European Commission, has instructed a Commissioner-designate for Trade Phil Hogan to 'use our trade tools to support sustainable development' as 'every new trade agreement concluded will have a dedicated chapter on sustainable development'. Moreover, the Commissioner should work with a newly created position of Chief Enforcement Officer in order to closely monitor the implementation of climate, environmental and labour protections enshrined in EU FTAs. ${ }^{90}$ This direction will be likely supported by the Council, as some Member States call for stringent rules in the TSD chapter. For instance, France openly advocates the implementation of binding sustainable development provisions where non-compliance may be subject to a dispute settlement mechanism. ${ }^{91}$

\footnotetext{
86 European Parliament, 'Resolution of 26 October 2017 Containing the Parliament's Recommendation to the Council on the Proposed Negotiating Mandate for Trade Negotiations with Australia' (2017) 19(g).

87 Commission, 'EU Team in Korea for Government Consultations over Labour Commitments under the Trade Agreement' (21 January 2019).

88 European Parliament, 'Resolution of 15 November 2018 on Vietnam, Notably the Situation of Political Prisoners' (2018).

89 Iana Dreyer, 'Comment: Greener or Messier EU Trade Policy Going Forward?’ Borderlex (28 May 2019).

90 Commission, 'Mission letter to Phil Hogan, Commissioner-designate for Trade' (10 September 2019) 5 .

91 Ministry for Europe and Foreign Affairs, 'The French Government's Trade Policy' <www. diplomatie.gouv.fr/en/french-foreign-policy/economic-diplomacy-foreign-trade/thefrench-government-s-trade-policy/ $\geq$ accessed 17 September 2019.
} 
However, there is further potential for expanding and heightening the specificity of provisions on labour, environmental protection, climate change, corporate social responsibility and responsible business conduct, etc. An ambitious and perhaps necessary ${ }^{92}$ development in this direction can have an impact on the division of competence, and ultimately re-introduce mixity in FTAs, even without investment protection.

The Court stressed that the purpose of the chapter is not to harmonise the social and environmental legislations of the Parties. ${ }^{93}$ However, the subsequent implementation of the EUSFTA could eventually lead to the Parties' effort for synergy and new commitments in these fields. ${ }^{94}$ Such a trend is already visible in the case of the CETA. In September 2018, the CETA Joint Committee issued its Recommendation on Trade, Climate Action and the Paris Agreement, recognising 'the importance of achieving the purpose and goals of the Paris Agreement' and recommending

that the Parties cooperate, work together and take joint actions as relevant to address climate change and promote the mutual supportiveness of trade and climate policies, rules and measures thereby contributing to the purpose and goals of the Paris Agreement and the transition to low greenhouse gas emissions and climate-resilient development'. ${ }^{95}$

Reading the recommendation, there is a clearly expressed intention of the Parties to develop deeper cooperation under the FTA framework in the future. Current provisions on sustainable development can thus serve as a platform for the extensive application and interpretation of the CETA, consequently possibly going beyond the limits of exclusive competence found by the Court in Opinion 2/15. The approach will be likely promoted by the EU in regard to other FTAs concluded or currently under negotiation.

It is important to add that under new FTAs, sustainable development can become the concern not only of the Parties, but also of investors. Comprehensive FTAs provide important opportunities for aligning international objectives of legal protection for foreign investors and sustainable development. From this perspective, for some authors, imposing actionable responsibilities constitutes the next logical step for compre-

\footnotetext{
92 See discussion in Martin Sandbu, 'Europe Uses Trade Deals to Push for Climate Change Action', Financial Times (London 8 July 2019) <www.ft.com/content/6d026308-9f0e-11e9b8ce-8b459ed04726 $\geq$ accessed 15 July 2019.

93 Opinion A-2/15 (n 22) para 165.

${ }_{94}$ Charlotte Beaucillon, 'Opinion 2/15: Sustainable Is the New Trade. Rethinking Coherence for the New Common Commercial Policy' (2017) 2(3) European Papers 827.

95 Recommendation 001/2018 of the CETA Joint Committee on trade, climate action and the Paris Agreement (26 September 2018).
} 
hensive FTAs. ${ }^{96}$ Arbitral or judicial innovation may also be a possible development with regard to investor responsibilities. ${ }^{97}$ Some EU Member States have begun to promote and deepen sustainable development standards in their new model bilateral treaties ${ }^{98}$ and the EU as a whole may start developing a similar approach soon.

A more active approach in this direction should also be welcomed from the systematic perspectives of the CCP under the Treaties. According to Article 207(1) TFEU, the CCP must be formulated and implemented in accordance with the general objectives and principles of EU external relations stipulated in Article 9 TFEU and Articles 3(5) and 21 TEU. ${ }^{99}$ Moreover, civil society and the trade unions in the EU consider sustainable development to be an essential element of trade policy. If chapters in the FTAs become more effective in promoting EU standards, they have the potential to improve the negative public perception of FTAs and the CCP in general.

Finally, evidence has already been provided that despite the exclusive nature of the current TSD chapter, the Member States are still able to intervene strongly in FTA negotiations. Allegedly, France resolutely calls on the EU to make a new policy in trade negotiations: "No Paris Agreement, no trade agreement'. ${ }^{100}$ In this way, France practically threatens to stand against each FTA which does not include Paris Agreement references. Member States can thus still block any FTA politically or legally in the Council if they assess sustainable development commitment as unsatisfactory.

\footnotetext{
96 Peter Muchlinski, 'Negotiating New Generation International Investment Agreements' in Steffen Hindelang and Markus Krajewski (eds), Shifting Paradigms in International Investment Law: More Balanced, Less Isolated, Increasingly Diversified (OUP 2016) 41; Belen Olmos Giupponi, 'Squaring the Circle? Balancing Sustainable Development and Investment Protection in the EU Investment Policy' (2016) 25(2) European Energy and Environmental Law Review 49-52; Emily R Hush, 'Where No Man Has Gone Before: The Future of Sustainable Development in the Comprehensive Economic and Trade Agreement and New Generation Free Trade Agreements' (2018) 43(1) Columbia Journal of Environmental Law 157; Maria Chochorelou and Carlos E Berdd, 'Sustainable Development in New Generation FTAs: Could Arbitrators Further the Principle through ISDS?' (2018) 27(2) Review of European, Comparative and International Environmental Law 185.

97 Urbaser SA et al $v$ Argentina, ICSID Case No ARB/07/26; Burlington Resources, Inc $v$ Ecuador, ICSID Case No ARB/08/5.

98 Netherlands Model Agreement on Reciprocal Promotion and Protection of Investments (2019); Belgium-Luxembourg Economic Union (BLEU) Model Agreement on Reciprocal Promotion and Protection of Investments (2019).

99 Angelos Dimopoulos, 'The Effects of the Lisbon Treaty on the Principles and Objectives of the Common Commercial Policy' (2010) 15 European Foreign Affairs Review 153.

100 Gregory Viscusi, 'Macron Says No Trade Deals Without Climate Treaty Compliance', Bloomber (25 September 2018) <www.bloomberg.com/news/articles/2018-09-25/macronsays-no-trade-deals-without-complying-with-climate-treaty $\geq$ accessed 29 June 2019.
} 


\section{Conclusion}

The Court's case law on the CCP is a remarkable tale of expanding exclusive external competence of the Union which has enabled the EU to become a global trade power. Opinion 2/15 on the EUSFTA was the first opportunity for the Court to comprehensively assess the post-Lisbon $\mathrm{CCP}$, including the scope of foreign direct investment. Accordingly, the Opinion undoubtedly has significant consequences for any recently concluded, ongoing or future trade and investment negotiations, including the EUSFTA itself. This will have a systematic impact on the whole of the CCP as FTAs have become the dominant form of trade cooperation of our times, achieving market opening as well as better regulatory governance. ${ }^{101}$ At the same time, trade policy becomes more contentious and politicised than ever before. The debate about costs and benefits of FTAs continues and its focus shifts to the concept of fair trade.

This development has a potential to draw further negative public attention. As opposition to trade negotiations with Canada and the United States showed, the campaign mobilised by European NGOs against both FTA negotiations heavily influenced public opinion in the short term, and represented the largest civil society movement in the EU's history. ${ }^{102}$ In spite of the fact that Eurobarometer data currently shows that over $70 \%$ of Europeans support the CCP and consider free trade to be positive, ${ }^{103}$ this recent history indicates that maintaining public support will not always be simple. The EU should face internal challenges with innovative, inclusive and courageous thinking.

Mixity does not imply an easy route for the ratification of any international agreement signed by the EU and its Member States. Actions by national or regional parliaments, interventions of stakeholders and rulings by national courts may threaten the successful conclusion of FTAs in the future, as the example of the CETA has proved. ${ }^{104}$ But the Commission's decision to separate the trade and investment parts of FTA negotiations, for the sake of exclusivity, is not a sign of brave thinking.

The 'Trade for All' strategy shows that the Commission has been more attentive to public concerns. The EU has already slowly embraced

\footnotetext{
101 Andreas Dür and Manfred Elsig, 'Introduction: The Purpose, Design and Effects of Preferential Trade Agreements' in Andreas Dür and Manfred Elsig (eds), Trade Cooperation: The Purpose, Design and Effects of Preferential Trade Agreements (CUP 2015) 1, 19.

102 Kurt Hübner, Anne-Sophie Deman and Tugce Balik, 'EU and Trade Policy-making: The Contentious Case of CETA' (2017) 39(7) Journal of European Integration 853.

103 Commission, 'Special Eurobarometer 461' (April 2017); Commission, 'Standard Barometer 89: Spring' (March 2018).

104 The agreement is still under the process of ratification in all of the thirty-eight national and regional parliaments.
} 
FTAs as an instrument for sustainability. Sustainable development remains, after Opinion 2/15, within the scope of the CCP. Nevertheless, the expansion of the scope in this field is limited within the boundaries of exclusivity. To address internal challenges of the CCP in terms of popular legitimacy and to manage expectations, the EU institution will likely need to advance beyond those boundaries. In the light of volatile public and political support for the CCP and free trade in general, sustainable development and the wider promotion of non-commercial interests can signal a positive dimension of FTAs for the public. Regarding investment protection, mixity is here to stay, particularly in the case of ISDS or similar mechanisms, where mandatory mixity is to be preserved. In addition, any effort for a simpler procedure in concluding exclusive FTAs may come at the expense of incorporating new areas into FTAs such anti-corruption or consumer protection ${ }^{105}$ which could add further elements of mixity to those agreements. Decoupling investment protection from trade aspects may also be detrimental to the coherence and ambitions of the EU investment policy to be a leading figurehead shaping and reforming international investment law, even if it ensures public support for new agreements in the short-term. ${ }^{106}$

Many challenges lie ahead for the CCP in terms of enhancing sustainable development standards and providing investment protection at the same time. Comprehensive FTAs encompassing trade, investment and sustainability deserve a second thought.

\section{(C) $(1) \Theta$}

This work is licensed under the Creative Commons Attribution - Non-Commercial - No Derivatives 4.0 International License.

Suggested citation: O Svoboda, 'The Common Commercial Policy after Opinion 2/15: No Simple Way to Make Life Easier for Free Trade Agreements in the EU' (2019) 15 CYELP 189

\footnotetext{
105 Areas highlighted by the European Parliament for future trade strategy. European Parliament, 'Resolution of 5 July 2016 on a New Forward-looking and Innovative Future Strategy for Trade and Investment' (2015).

106 Gáspár-Szilágyi (n 51) 182-183.
} 